\title{
Optimizing the Pratt-type titrimetric method to determine FeO in geochemical reference materials
}

\author{
AtsunOri NAKAMURA,* TAKAshi OKAi and Atsuyuki OHTA \\ Geological Survey of Japan, National Institute of Advanced Industrial Science and Technology (AIST), \\ Tsukuba Central 7, 1-1-1 Higashi, Tsukuba, Ibaraki 305-8567, Japan
}

(Received April 8, 2020; Accepted June 27, 2020)

\begin{abstract}
Determination of ferrous iron $(\mathrm{FeO})$ is important across a wide breadth of disciplines in geochemistry. The certified values of $\mathrm{FeO}$ in geochemical reference materials have been determined mainly by wet chemistry. During this procedure, special attention is needed to prevent oxidation of $\mathrm{Fe}^{2+}$ to $\mathrm{Fe}^{3+}$, which may lead to underestimations of $\mathrm{FeO}$ mass fractions. Here, we revisited a traditional titrimetric method to provide a better method of determining the FeO mass fractions in geochemical reference materials. We investigated the effect of duration of decomposition, sand bath temperature, and sample weight. Among these, we found that the effect of sample weight on the $\mathrm{FeO}$ values is most significant. The FeO values increase with increasing sample weight, indicating that vapor and foam effectively prevent oxidation. This is supported by yield tests and experiments involving the addition of $\mathrm{SiO}_{2}$ powder to the samples. Thus, we suggest the use of greater amounts of sample to minimize oxidation. We further compare our results with the published recommended values for reference materials, demonstrating that the latter need be considered carefully. The approach described here is not only applicable to geochemical reference materials but also useful to unknown geological samples.
\end{abstract}

Keywords: titration, $\mathrm{FeO}$, ferrous iron, wet chemistry, geochemical reference material

\section{INTRODUCTION}

Iron has two oxidation states, $\mathrm{Fe}^{2+}$ and $\mathrm{Fe}^{3+}$, in silicate rocks. In general, instrumental analyses are not suitable for accurately detecting each oxidation state separately; therefore, $\mathrm{FeO}$ is usually analysed by traditional wet chemistry. While $\mathrm{FeO}$ mass fractions are determined by titration, $\mathrm{Fe}_{2} \mathrm{O}_{3}$ mass fractions are determined by subtracting those of $\mathrm{FeO}$ concentrations from the total $\mathrm{Fe}$ concentrations. The abundances of each oxidation state and their ratios are used widely in diverse disciplines in geochemistry; for example, they are essential for normative calculation (Middlemost, 1989; Verma et al., 2002). The ratio of $\mathrm{Fe}_{2} \mathrm{O}_{3}$ to total $\mathrm{Fe}$ is also crucial for estimating the oxygen fugacity of the mid-ocean ridge basaltic glasses (Christie et al., 1986; Bézos and Humler, 2005). Furthermore, it is a useful proxy with which to understand the great oxidation event during the history of the Earth that led to atmospheric oxygen reaching nearpresent levels (Stolper and Keller, 2018).

In wet chemical analysis, geochemical reference materials are treated as unknown samples. The measured

*Corresponding author (e-mail: nakamura-a@ aist.go.jp)

Copyright $\odot 2020$ by The Geochemical Society of Japan. values are validated by comparisons with the measured value of the reference materials. Among various types of wet chemical analyses, titrimetric methods are one of the most classical methods used to measure $\mathrm{FeO}$ values. Although titrimetric methods yield accurate $\mathrm{FeO}$ values, it is time consuming. Much progress has been made on measuring $\mathrm{FeO}$ using analytical instruments; this includes new methods such ion chromatography (Kanai, 1990; le Roex and Watkins, 1995), Mössbauer spectroscopy (Lalonde et al., 1998), phenanthroline spectrophotometry (Husler et al., 2011; Tarafder and Thakur, 2013), X-ray absorption near-edge structure (XANES) spectroscopy (Farges, 2001; Ohta et al., 2006; O'Neill et al., 2006, 2018; Berry et al., 2010, 2018; Cottrell and Kelley, 2011; Zhang et al., 2018), and electron probe microanalysis (EPMA) (Hughes et al., 2018; Li et al., 2019). In each of these developments, it is crucial to compare the results of unknown geological samples with geochemical reference materials; therefore, the importance of geochemical reference materials with certified values is increasing.

The certified values of geochemical reference materials have previously been determined mainly by a titrimetric method. During this method, samples are first decomposed by sulphuric acid $\left(\mathrm{H}_{2} \mathrm{SO}_{4}\right)$ and hydrofluoric acid (HF) in crucibles. They are then titrated with a potassium dichromate $\left(\mathrm{K}_{2} \mathrm{Cr}_{2} \mathrm{O}_{7}\right)$ solution to allow volumetric calculation of the amounts of $\mathrm{FeO}$. The difficulty arises 
(a)

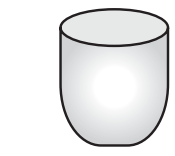

Weigh sample in a platinum crucible

(d)

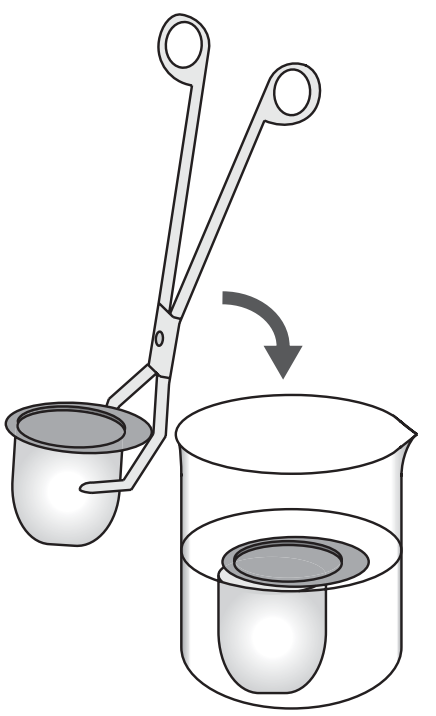

Pour $50 \mathrm{ml} \mathrm{B}(\mathrm{OH})_{3}(4 \%)$

and $130 \mathrm{ml}$ deionized water into a beaker Grasp the crucible with platinum tipped tongs and place the crucible in the beaker (b)

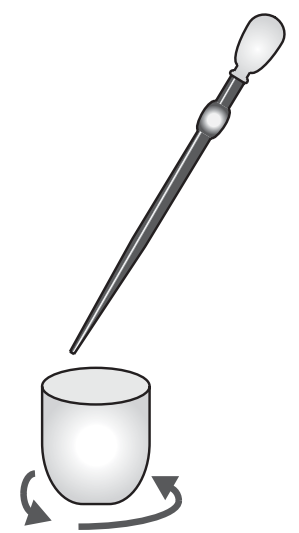

Add deionized water Swirl the crucible

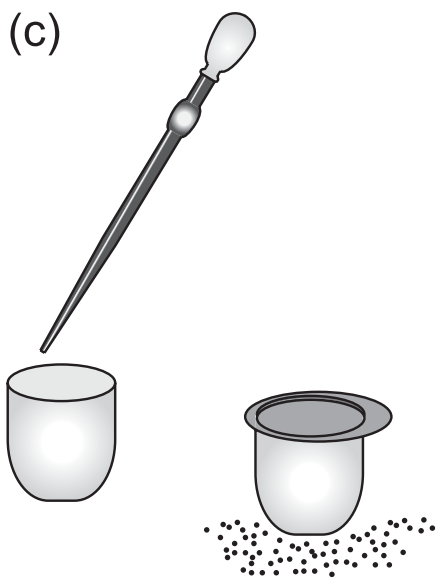

Add $5 \mathrm{ml} \mathrm{H}_{2} \mathrm{SO}_{4}\left(9 \mathrm{~mol} \mathrm{l}^{-1}\right)$ and $8 \mathrm{ml} \mathrm{HF}(50 \%)$ Place the crucible on a sand bath Place a cover on the crucible (e)

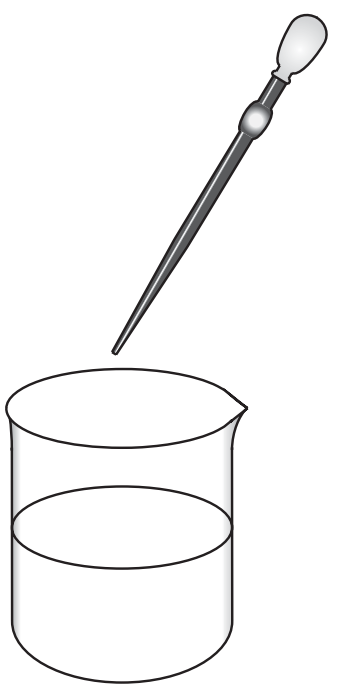

Rinse off the crucible and the cover Add $10 \mathrm{ml} \mathrm{H}_{2} \mathrm{SO}_{4}\left(9 \mathrm{~mol} \mathrm{I}^{-1}\right)$ Add $5 \mathrm{ml} \mathrm{H}_{3} \mathrm{PO}_{4}\left(7.5 \mathrm{~mol} \mathrm{I}^{-1}\right)$ Add 5 drops of sodium diphenylamine-4-sulphonate $(0.25 \%)$

Fig. 1. Titrimetric analysis of $\mathrm{FeO}$. (a) Weighing the sample. (b) Adding the deionized water and swirling. (c) Decomposition of the sample in $\mathrm{H}_{2} \mathrm{SO}_{4}$ and $\mathrm{HF}$. (d) Masking $\mathrm{HF}$ with $\mathrm{B}(\mathrm{OH})_{3}$. (e) Adding $\mathrm{H}_{2} \mathrm{SO}_{4}, \mathrm{H}_{3} \mathrm{PO}_{4}$, and sodium diphenylamine-4-sulphonate. (f) Titration with $\mathrm{K}_{2} \mathrm{Cr}_{2} \mathrm{O}_{7}$.

from the fact that $\mathrm{Fe}^{2+}$ is easily oxidized to $\mathrm{Fe}^{3+}$ during sample decomposition, leading to lower FeO values (Schafer, 1966a; Maxwell, 1968; Lalonde et al., 1998; Bézos and Humler, 2005; Xue et al., 2017). Thus, it is necessary to avoid oxidation of $\mathrm{Fe}^{2+}$ during the acid decomposition as much as possible. Here, we revisited the method to provide a better way to determine the FeO mass fractions in geochemical reference materials. We first examined the appropriate duration and temperature of sample decomposition. We then investigated the effect of sample weight on the $\mathrm{FeO}$ values and demonstrated that treatment with larger sample sizes effectively prevents oxidation during decomposition. We confirmed this with yield tests on $\mathrm{Fe}^{2+}$ and experiments involving addition of pure $\mathrm{SiO}_{2}$ powder to the samples. The approach described here is not only applicable to reference materials but also useful on unknown geological samples. 


\section{Wet Chemistry}

\section{Titrimetric determination of $\mathrm{FeO}$}

The mass fractions of $\mathrm{FeO}$ were measured by a modified version of the "Pratt method" (Maxwell, 1968). This titrimetric method has been applied to determine the certified values of $\mathrm{FeO}$ in geochemical reference materials issued by the Geological Survey of Japan (GSJ) (Terashima and Ando, 1987; Imai et al., 1995). The method is the classical and simplest method among the various versions of the wet chemical method (Schafer, 1966a, 1966b). The details are slightly different from the original (Pratt, 1894), but the key concepts remain unchanged. We provide the full procedure here, because: (1) numerous versions of the "Pratt method" exist and none of these are the same and (2) the procedure at each step is often critical in wet chemistry, such that a detailed explanation is required to allow independent investigators to repeat the experiments.

First, the geochemical reference materials-which were supplied as ground rock powder-were weighed in 30 or $50 \mathrm{ml}$ platinum crucibles (Fig. 1). To prevent caking during the following decomposition procedure, $3 \mathrm{ml}$ of deionized water was added to these and the crucibles were swirled. This suspended the powders in the water. Second, $5 \mathrm{ml}$ of $9 \mathrm{~mol} \mathrm{l}^{-1} \mathrm{H}_{2} \mathrm{SO}_{4}$ and $8 \mathrm{ml}$ of $50 \% \mathrm{HF}$ were added for decomposition. The crucibles were placed immediately on a sand bath, the temperature of which was $150-170^{\circ} \mathrm{C}$, for $3-20$ minutes. Covers were placed on the crucibles during this procedure. While this was happening, mixtures of $50 \mathrm{ml}$ of $4 \%$ boric acid and $130 \mathrm{ml}$ of deionized water were prepared in plastic beakers. When the decomposition procedure was completed, the covered crucibles were grasped with platinum tipped tongs. The outside of the bottom part of the crucibles were rinsed with deionized water and then the crucibles were dropped into beakers in order to mask the HF. The crucibles were entirely immersed in the solution. The crucibles and the covers were then rinsed off with small amounts of deionized water. All the contents in the crucibles were washed into the beaker. Third, $10 \mathrm{ml}$ of $9 \mathrm{~mol} \mathrm{l}^{-1} \mathrm{H}_{2} \mathrm{SO}_{4}$ and $5 \mathrm{ml}$ of $7.5 \mathrm{~mol}^{-1}$ phosphoric acid $\left(\mathrm{H}_{3} \mathrm{PO}_{4}\right)$ were added for redox titration. The solutions were gently stirred with rods before and after the addition of 5 drops of $0.25 \%$ sodium diphenylamine-4-sulphonate as an indicator. Finally, the solutions were titrated with a $\mathrm{K}_{2} \mathrm{Cr}_{2} \mathrm{O}_{7}$ solution prepared in advance. Depending on the amounts of $\mathrm{FeO}$ in the samples, the concentration of the $\mathrm{K}_{2} \mathrm{Cr}_{2} \mathrm{O}_{7}$ solution was selected from $1 / 60,1 / 120$, or $1 / 240 \mathrm{~mol} \mathrm{l}^{-1}$. As the end point was being approached, the solutions turned a greenish colour. The end point was reached with the first appearance of a homogeneous violet colour. The change in colour to violet was drastic with only one drop of the $\mathrm{K}_{2} \mathrm{Cr}_{2} \mathrm{O}_{7}$ solution, such that the end point was easily rec- ognized. After making a note on the volume of titrant solution, another drop of the $\mathrm{K}_{2} \mathrm{Cr}_{2} \mathrm{O}_{7}$ solution was added to determine whether the change in colour occurred or not. The $\mathrm{K}_{2} \mathrm{Cr}_{2} \mathrm{O}_{7}$ solution was prepared from solid $\mathrm{K}_{2} \mathrm{Cr}_{2} \mathrm{O}_{7}$ certified reference material for volumetric analysis supplied from Kanto Chemical Co. All other chemicals were analytical grade. We did not introduce a system to treat samples under an anoxic environment employing inert gas flow because we are determining $\mathrm{FeO}$ values of the reference materials in collaboration with eight other laboratories. In previous studies, much effort has been spent to prevent oxidation of $\mathrm{Fe}^{2+}$ by introducing specific apparatus enabling sample decomposition under an inert gas atmosphere (Cooke, 1867; Pratt, 1894; Hillebrand, 1907; Barnebey, 1915; Schafer, 1966a, b). The system of continuous gas flow has been further modified with the recent development of modern instruments (Xue et al., 2017). Though we acknowledge these developments, the complex nature of the involved apparatus sometimes limits their use in laboratories, in addition to the fact that such systems are often too costly for most laboratories to employ. Instead, we aimed to optimize the method with an easy method of minimizing oxidation during sample decomposition, without employing specific apparatus.

The uncertainties propagated through to the combined standard uncertainties of the $\mathrm{FeO}$ mass fractions. The combined standard uncertainties include the uncertainties of sample weight, the uncertainties of the volume of the burette, the uncertainties of the read values of the burette, the uncertainties of the weight of $\mathrm{K}_{2} \mathrm{Cr}_{2} \mathrm{O}_{7}$, and the uncertainties of the volume of the volumetric flask used to adjust the $\mathrm{K}_{2} \mathrm{Cr}_{2} \mathrm{O}_{7}$ solution. The resultant uncertainties were mainly derived from the uncertainties of the volume of the burette and those of the read values of the burette.

\section{Recovery yield measurements of $\mathrm{Fe}^{2+}$}

We conducted two types of recovery yield tests. Solid ammonium iron(II) sulphate hexahydrate was used for the first type of tests, whereas $\mathrm{Fe}^{2+}$ solution was used for the second type of tests. The titrimetric procedure followed was the same as that described earlier. Amorphous $\mathrm{SiO}_{2}$ powder supplied by Kanto Chemical Co. (high purity reagent, $>99.9 \%$ purity, grain size of $c a .36 \mu \mathrm{m}$ ) was ground in a clean agate mortar to prepare fine pure $\mathrm{SiO}_{2}$ powder that was easily suspended in deionized water. The grain size was measured using a laser scattering particle analyzer (HORIBA LA-920). The mean grain size of the ground $\mathrm{SiO}_{2}$ powder was $14 \mu \mathrm{m}$. A quantity of $0-3 \mathrm{~g}$ of this $\mathrm{SiO}_{2}$ powder was weighed in platinum crucibles for each type of recovery test. This was done to mimic increasing sample weights. In the first type of tests, $0.25 \mathrm{~g}$ of solid ammonium iron(II) sulphate hexahydrate was first 
(a)

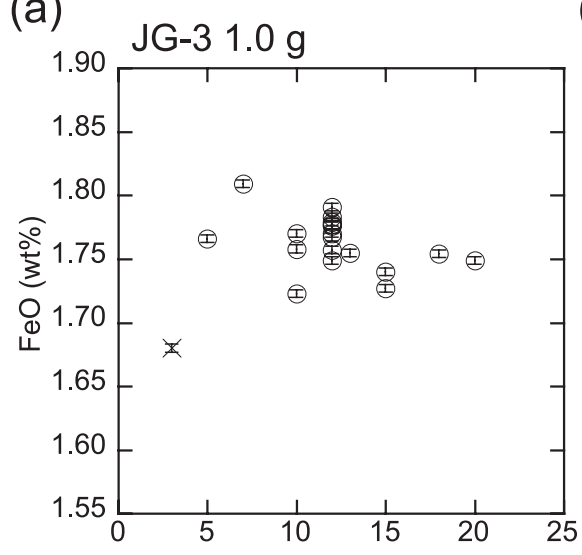

(d)

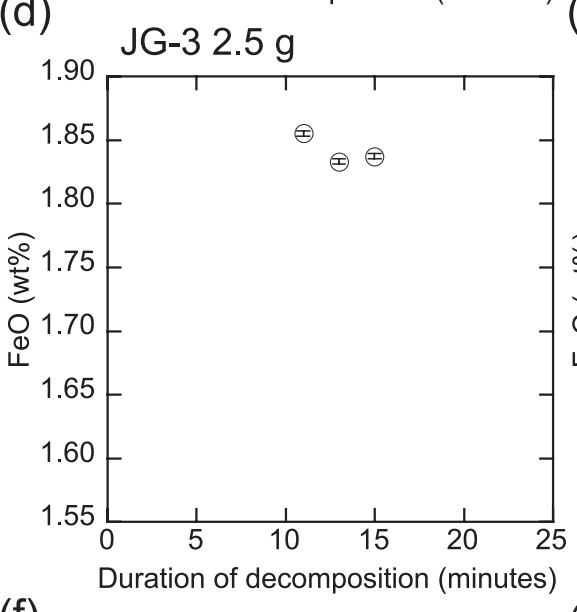

(f)

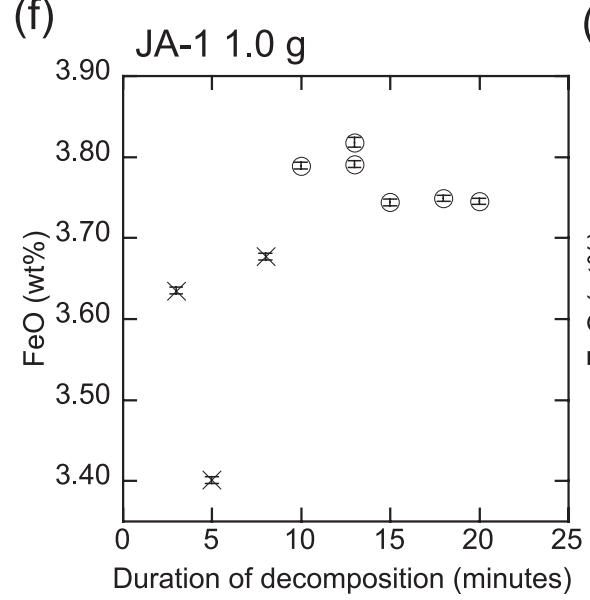

(b)

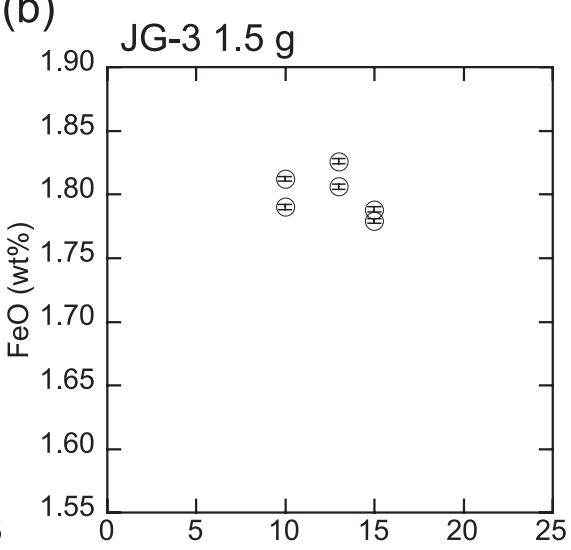

(e)

Duration of decomposition (minutes)

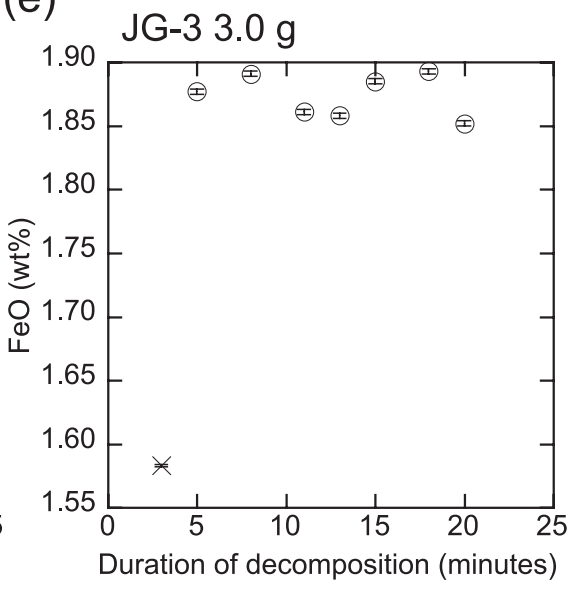

(c)

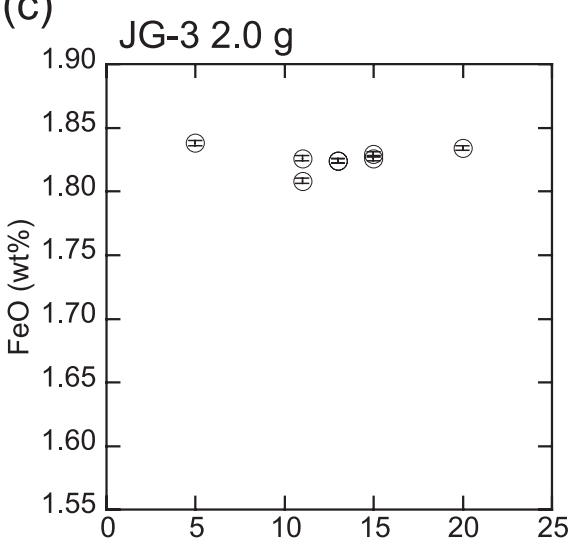

Duration of decomposition (minutes)

(g)

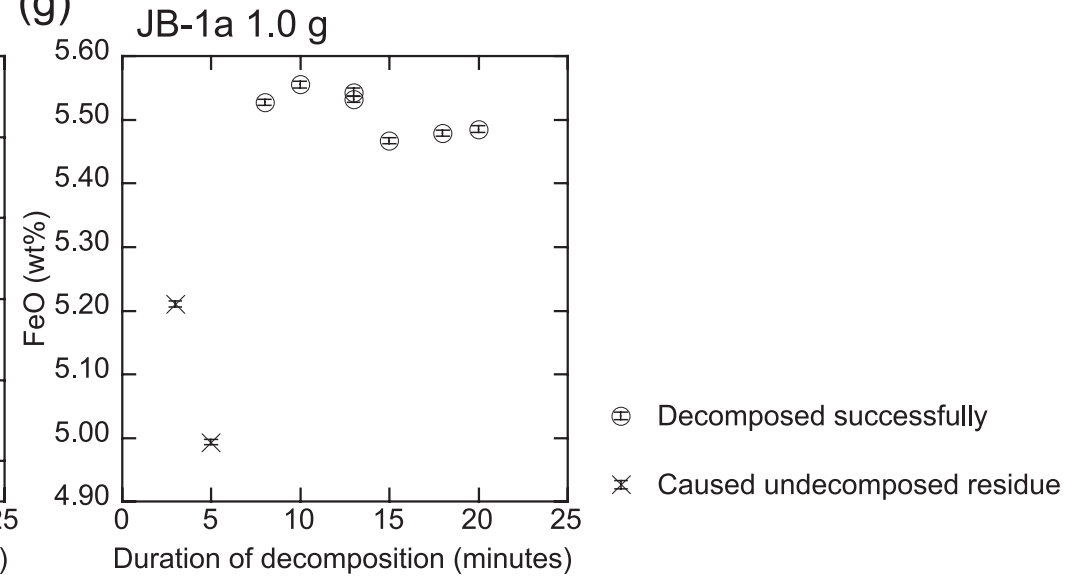

Fig. 2. Comparison of decomposition duration and FeO values for different sample weights. (a) $1.0 \mathrm{~g}$ of JG-3. (b) $1.5 \mathrm{~g}$ of JG-3. (c) $2.0 \mathrm{~g}$ of $J G-3$. (d) $2.5 \mathrm{~g}$ of $\mathrm{JG}-3$. (e) $3.0 \mathrm{~g}$ of $\mathrm{JG}-3$. (f) $1.0 \mathrm{~g}$ of JA-1. ( $\mathrm{g}$ ) $1.0 \mathrm{~g}$ of JB-1a. Range bars show combined standard uncertainties.

weighed in small quartz crucibles. The platinum crucibles were swirled with deionized water. After adding $\mathrm{H}_{2} \mathrm{SO}_{4}$ and $\mathrm{HF}$, the platinum crucibles were placed on a sand bath. The quartz crucibles were then dropped into the platinum crucibles two minutes after HF was added to the latter. Covers were quickly placed on the crucibles, which were then kept on the sand bath for a total of 13 min. This condition was employed to reproduce the conditions similar to those of the actual samples wherein minerals were decomposed and $\mathrm{Fe}^{2+}$ was released into 


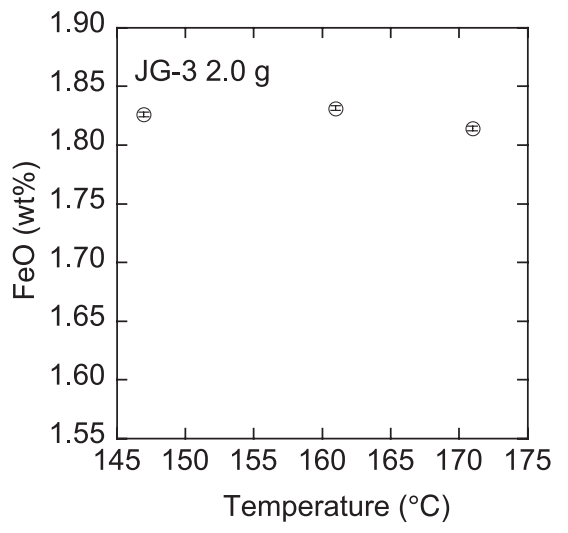

Fig. 3. Comparison of decomposition temperature and $\mathrm{FeO}$ values. Sample weights are $2.0 \mathrm{~g}$ of JG-3. Range bars show combined standard uncertainties.

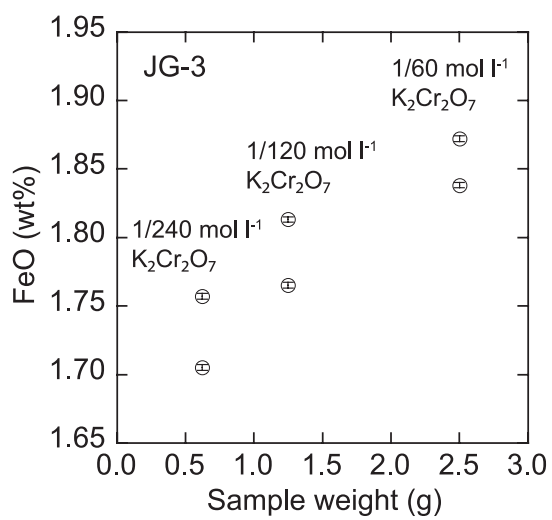

Fig. 4. The effect of sample weight on FeO values. Sample sizes of JG-3 for analysis were doubled and quadrupled, while the concentrations of the $\mathrm{K}_{2} \mathrm{Cr}_{2} \mathrm{O}_{7}$ solutions were also doubled $\left(1 / 120 \mathrm{~mol} \mathrm{l}^{-1}\right)$ and quadrupled $\left(1 / 60 \mathrm{~mol} \mathrm{l}^{-1}\right)$, respectively. This enabled the volume of consumed $\mathrm{K}_{2} \mathrm{Cr}_{2} \mathrm{O}_{7}$ solution to be maintained approximately constant. Range bars show combined standard uncertainties.

the solution in hot HF. The procedure of titrimetric determining $\mathrm{Fe}^{2+}$ with $\mathrm{K}_{2} \mathrm{Cr}_{2} \mathrm{O}_{7}$ solution was the same as that described earlier.

For the second type of tests, $0.3 \mathrm{mmol} \mathrm{g}{ }^{-1} \mathrm{Fe}^{2+}$ solution in $1 \mathrm{~mol} \mathrm{l}^{-1} \mathrm{H}_{2} \mathrm{SO}_{4}$ was prepared from solid ammonium iron(II) sulphate hexahydrate. After weighing 0-3 $\mathrm{g}$ of $\mathrm{SiO}_{2}$ powder in platinum crucibles, the crucibles were swirled with deionized water and $2.2 \mathrm{~g}$ of the $\mathrm{Fe}^{2+}$ solution was then added to it. The decomposition procedure followed thereafter was the same. The second type of test reflected the worst-case scenario of having $\mathrm{Fe}^{2+}$ in solution from the beginning, which was not the case in the actual samples.

The molar concentration and the uncertainty of the (a)
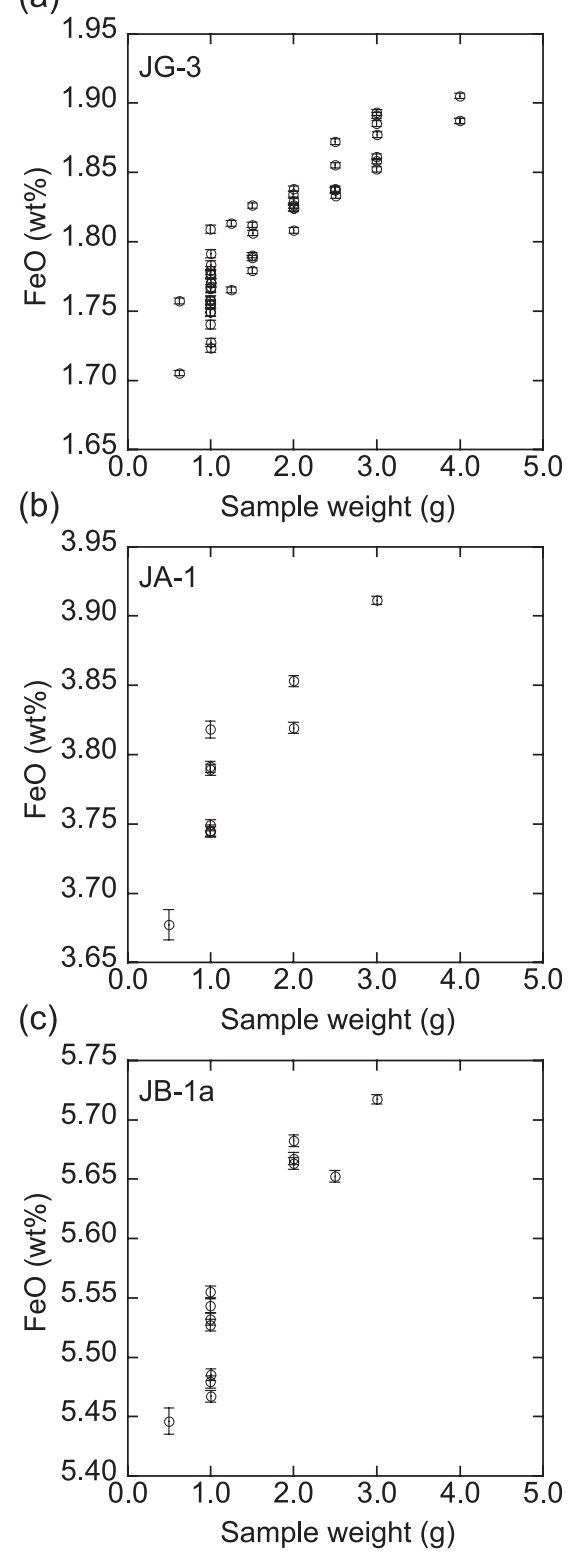

Fig. 5. The effect of sample weight on $\mathrm{FeO}$ values. FeO values increase with increasing sample weight until the sample weight reaches the weight that causes boil over and/or remaining undecomposed residues. (a) Plot of compiled $\mathrm{FeO}$ values for $J G$-3. Analyses with insufficient decomposition duration are not included. Samples heavier than $4 \mathrm{~g}$ resulted in boil over and/or remaining undecomposed residues. (b) Plot for JA-1. (c) Plot for JB-1a. Samples heavier than $3 \mathrm{~g}$ resulted in boil over for $J A-1$ and JB-1a. In the meantime, there were remaining undecomposed residues. Range bars show combined standard uncertainties.

$\mathrm{Fe}^{2+}$ solution was determined via five repeatable titrations with $1 / 120 \mathrm{~mol} \mathrm{l}^{-1} \mathrm{~K}_{2} \mathrm{Cr}_{2} \mathrm{O}_{7}$. The uncertainties of the added $\mathrm{Fe}^{2+}$ weight, the tolerance of the burette, the uncertainties in the read values of the burette, the uncer- 
Table 1. Sample details and FeO determinations

\begin{tabular}{|c|c|c|c|c|c|c|c|}
\hline Sample $^{\mathrm{a}}$ & $\begin{array}{c}\text { Sample } \\
\text { weight (g) }\end{array}$ & $\begin{array}{l}\text { Crucible } \\
\text { size }(\mathrm{ml})\end{array}$ & $\begin{array}{l}\text { Decomposition } \\
\text { temperature }\left({ }^{\circ} \mathrm{C}\right)\end{array}$ & $\begin{array}{l}\text { Decomposition } \\
\text { duration (min) }\end{array}$ & $\begin{array}{l}\mathrm{K}_{2} \mathrm{Cr}_{2} \mathrm{O}_{7} \\
\left(\mathrm{~mol} \mathrm{l}^{-1}\right)\end{array}$ & $\begin{array}{c}\mathrm{FeO} \\
(\mathrm{wt} \%)^{\mathrm{b}}\end{array}$ & Remarks $^{c}$ \\
\hline JG-3 & 1.0031 & 30 & 155 & 5 & $1 / 120$ & $1.766 \pm 0.003$ & \\
\hline JG-3 & 1.0030 & 30 & 154 & 7 & $1 / 120$ & $1.809 \pm 0.003$ & \\
\hline $\mathrm{JG}-3$ & 1.0000 & 30 & 154 & 12 & $1 / 120$ & $1.779 \pm 0.003$ & \\
\hline $\mathrm{JG}-3$ & 1.0037 & 30 & 156 & 18 & $1 / 120$ & $1.754 \pm 0.003$ & \\
\hline $\mathrm{JG}-3$ & 1.0004 & 30 & 152 & 20 & $1 / 120$ & $1.749 \pm 0.003$ & \\
\hline $\mathrm{JG}-3$ & 3.0013 & 30 & 157 & 20 & $1 / 120$ & $1.852 \pm 0.003$ & \\
\hline $\mathrm{JG}-3$ & 1.0032 & 30 & 157 & 3 & $1 / 120$ & $1.680 \pm 0.003$ & undecomposed residue \\
\hline JG-3 & 1.0016 & 30 & 154 & 10 & $1 / 120$ & $1.758 \pm 0.003$ & \\
\hline $\mathrm{JG}-3$ & 3.0026 & 30 & 157 & 3 & $1 / 120$ & $1.583 \pm 0.001$ & undecomposed residue \\
\hline $\mathrm{JG}-3$ & 3.0064 & 30 & 156 & 5 & $1 / 120$ & $1.877 \pm 0.002$ & \\
\hline $\mathrm{JG}-3$ & 3.0001 & 30 & 159 & 8 & $1 / 120$ & $1.891 \pm 0.002$ & \\
\hline JG-3 & 3.0026 & 30 & 157 & 18 & $1 / 120$ & $1.893 \pm 0.002$ & \\
\hline JG-3 & 1.0053 & 30 & 152 & 12 & $1 / 120$ & $1.791 \pm 0.003$ & \\
\hline JG-3 & 1.0028 & 30 & 151 & 12 & $1 / 120$ & $1.777 \pm 0.003$ & \\
\hline JG-3 & 1.0066 & 30 & 155 & 12 & $1 / 120$ & $1.767 \pm 0.003$ & \\
\hline JG-3 & 1.0044 & 30 & 155 & 12 & $1 / 120$ & $1.749 \pm 0.003$ & \\
\hline $\mathrm{JG}-3$ & 1.0054 & 30 & 156 & 12 & $1 / 120$ & $1.776 \pm 0.003$ & \\
\hline JG-3 & 1.0090 & 30 & 156 & 12 & $1 / 120$ & $1.770 \pm 0.003$ & \\
\hline JG-3 & 1.0052 & 30 & 153 & 10 & $1 / 120$ & $1.723 \pm 0.003$ & \\
\hline $\mathrm{JG}-3$ & 1.0001 & 30 & 150 & 12 & $1 / 120$ & $1.757 \pm 0.003$ & \\
\hline $\mathrm{JG}-3$ & 1.0014 & 30 & 153 & 15 & $1 / 120$ & $1.740 \pm 0.003$ & \\
\hline JG-3 & 1.0050 & 30 & 155 & 10 & $1 / 120$ & $1.770 \pm 0.003$ & \\
\hline $\mathrm{JG}-3$ & 1.0055 & 30 & 156 & 12 & $1 / 120$ & $1.783 \pm 0.003$ & \\
\hline JG-3 & 1.0048 & 30 & 154 & 15 & $1 / 120$ & $1.727 \pm 0.003$ & \\
\hline JG-3 & 1.5040 & 30 & 159 & 15 & $1 / 120$ & $1.779 \pm 0.002$ & \\
\hline JG-3 & 1.5059 & 30 & 162 & 13 & $1 / 120$ & $1.826 \pm 0.002$ & \\
\hline $\mathrm{JG}-3$ & 1.5041 & 30 & 159 & 10 & $1 / 120$ & $1.812 \pm 0.002$ & \\
\hline JG-3 & 1.5045 & 30 & 160 & 15 & $1 / 120$ & $1.788 \pm 0.002$ & \\
\hline JG-3 & 1.5089 & 30 & 158 & 13 & $1 / 120$ & $1.806 \pm 0.002$ & \\
\hline JG-3 & 1.5027 & 30 & 158 & 10 & $1 / 120$ & $1.790 \pm 0.002$ & \\
\hline $\mathrm{JG}-3$ & 2.0012 & 30 & 160 & 15 & $1 / 120$ & $1.829 \pm 0.002$ & \\
\hline JG-3 & 2.0017 & 30 & 161 & 13 & $1 / 120$ & $1.824 \pm 0.002$ & \\
\hline JG-3 & 2.0028 & 30 & 159 & 11 & $1 / 120$ & $1.826 \pm 0.002$ & \\
\hline $\mathrm{JG}-3$ & 2.0014 & 30 & 158 & 15 & $1 / 120$ & $1.826 \pm 0.002$ & \\
\hline JG-3 & 2.0018 & 30 & 159 & 13 & $1 / 120$ & $1.824 \pm 0.002$ & \\
\hline JG-3 & 2.0026 & 30 & 159 & 11 & $1 / 120$ & $1.808 \pm 0.002$ & \\
\hline JG-3 & 2.5005 & 30 & 162 & 15 & $1 / 120$ & $1.837 \pm 0.002$ & \\
\hline JG-3 & 2.5055 & 30 & 160 & 13 & $1 / 120$ & $1.833 \pm 0.002$ & \\
\hline $\mathrm{JG}-3$ & 2.5038 & 30 & 162 & 11 & $1 / 120$ & $1.855 \pm 0.002$ & \\
\hline JG-3 & 2.0012 & 30 & 147 & 13 & $1 / 120$ & $1.826 \pm 0.002$ & \\
\hline $\mathrm{JG}-3$ & 2.0018 & 30 & 161 & 13 & $1 / 120$ & $1.831 \pm 0.002$ & \\
\hline JG-3 & 2.0042 & 30 & 171 & 13 & $1 / 120$ & $1.814 \pm 0.002$ & \\
\hline JG-3 & 3.0001 & 30 & 159 & 15 & $1 / 120$ & $1.885 \pm 0.002$ & \\
\hline JG-3 & 3.0003 & 30 & 158 & 13 & $1 / 120$ & $1.858 \pm 0.002$ & \\
\hline $\mathrm{JG}-3$ & 3.0012 & 30 & 160 & 11 & $1 / 120$ & $1.861 \pm 0.002$ & \\
\hline $\mathrm{JG}-3$ & 3.5021 & 30 & 161 & 13 & - & - & boiled over \\
\hline JG-3 & 3.5055 & 30 & 160 & 11 & - & - & boiled over \\
\hline JG-3 & 1.0010 & 30 & 157 & 13 & $1 / 120$ & $1.755 \pm 0.003$ & \\
\hline JG-3 & 0.6256 & 30 & 160 & 13 & $1 / 240$ & $1.757 \pm 0.002$ & \\
\hline JG-3 & 0.6256 & 30 & 157 & 13 & $1 / 240$ & $1.705 \pm 0.002$ & \\
\hline $\mathrm{JG}-3$ & 1.2517 & 30 & 156 & 13 & $1 / 120$ & $1.813 \pm 0.002$ & \\
\hline JG-3 & 1.2511 & 30 & 159 & 13 & $1 / 120$ & $1.765 \pm 0.002$ & \\
\hline JG-3 & 2.5018 & 30 & 158 & 13 & $1 / 60$ & $1.872 \pm 0.002$ & \\
\hline JG-3 & 2.5013 & 30 & 157 & 13 & $1 / 60$ & $1.838 \pm 0.002$ & \\
\hline
\end{tabular}


Table 1. (continued)

\begin{tabular}{|c|c|c|c|c|c|c|c|}
\hline Sample $^{\mathrm{a}}$ & $\begin{array}{c}\text { Sample } \\
\text { weight }(\mathrm{g})\end{array}$ & $\begin{array}{l}\text { Crucible } \\
\text { size }(\mathrm{ml})\end{array}$ & $\begin{array}{l}\text { Decomposition } \\
\text { temperature }\left({ }^{\circ} \mathrm{C}\right)\end{array}$ & $\begin{array}{l}\text { Decomposition } \\
\text { duration (min) }\end{array}$ & $\begin{array}{l}\mathrm{K}_{2} \mathrm{Cr}_{2} \mathrm{O}_{7} \\
\left(\mathrm{~mol} \mathrm{1}^{-1}\right)\end{array}$ & $\begin{array}{c}\mathrm{FeO} \\
(\mathrm{wt} \%)^{\mathrm{b}}\end{array}$ & Remarks $^{\mathrm{c}}$ \\
\hline JG-3 & 4.0012 & 50 & 159 & 13 & $1 / 60$ & $1.905 \pm 0.002$ & \\
\hline JG-3 & 5.0035 & 50 & 159 & 13 & - & - & undecomposed residue \\
\hline JG-3 & 6.0001 & 50 & 157 & 13 & - & - & undecomposed residue \\
\hline JG-3 & 4.0031 & 50 & 160 & 13 & $1 / 60$ & $1.887 \pm 0.002$ & \\
\hline JG-3 & 5.0043 & 50 & 157 & 13 & - & - & undecomposed residue \\
\hline JG-3 & 6.0047 & 50 & 158 & 13 & - & - & undecomposed residue \\
\hline JG-3 & 4.0001 & 50 & 157 & 13 & $1 / 60$ & $1.887 \pm 0.002$ & \\
\hline JG-3 & 5.0008 & 50 & 160 & 13 & - & - & boiled over \\
\hline JG-3 & 6.0025 & 50 & 158 & 13 & - & - & boiled over, undecomposed residue \\
\hline JG-3 & 4.0020 & 50 & 160 & 13 & - & - & undecomposed residue \\
\hline JG-3 & 5.0016 & 50 & 158 & 13 & - & - & undecomposed residue \\
\hline JG-3 & 6.0027 & 50 & 156 & 13 & - & - & undecomposed residue \\
\hline JG-3 & 5.0006 & 50 & $150-160$ & 15 & - & - & boiled over \\
\hline JG-3 & 6.0018 & 50 & $150-160$ & 15 & - & - & boiled over, undecomposed residue \\
\hline JG-3 & 5.0004 & 50 & $150-160$ & 15 & - & - & boiled over, undecomposed residue \\
\hline JG-3 & 6.0015 & 50 & $150-160$ & 15 & - & - & boiled over, undecomposed residue \\
\hline JG-3 & 5.0011 & 50 & $150-160$ & 15 & - & - & undecomposed residue \\
\hline JG-3 & 6.0001 & 50 & $150-160$ & 15 & - & - & boiled over, undecomposed residue \\
\hline JA-1 & 1.0004 & 30 & 157 & 3 & $1 / 120$ & $3.635 \pm 0.004$ & undecomposed residue \\
\hline JA-1 & 1.0037 & 30 & 154 & 5 & $1 / 120$ & $3.401 \pm 0.004$ & undecomposed residue \\
\hline JA-1 & 1.0009 & 30 & 154 & 8 & $1 / 120$ & $3.677 \pm 0.004$ & undecomposed residue \\
\hline JA-1 & 1.0035 & 30 & 155 & 10 & $1 / 120$ & $3.789 \pm 0.004$ & \\
\hline JA-1 & 1.0002 & 30 & 156 & 13 & $1 / 120$ & $3.791 \pm 0.004$ & \\
\hline JA-1 & 1.0022 & 30 & 155 & 15 & $1 / 120$ & $3.744 \pm 0.004$ & \\
\hline JA-1 & 0.5000 & 30 & 152 & 13 & $1 / 60$ & $3.677 \pm 0.011$ & \\
\hline JA-1 & 1.0010 & 30 & 153 & 13 & $1 / 60$ & $3.818 \pm 0.006$ & \\
\hline JA-1 & 2.0023 & 30 & 154 & 13 & $1 / 60$ & $3.853 \pm 0.004$ & \\
\hline JA-1 & 2.5010 & 30 & 154 & 13 & - & - & boiled over, undecomposed residue \\
\hline JA-1 & 3.0037 & 50 & 152 & 13 & $1 / 60$ & $3.911 \pm 0.003$ & \\
\hline JA-1 & 4.0013 & 50 & 153 & 13 & - & - & boiled over, undecomposed residue \\
\hline JB-1a & 1.0002 & 30 & 154 & 3 & $1 / 120$ & $5.210 \pm 0.005$ & undecomposed residue \\
\hline JB-1a & 1.0012 & 30 & 155 & 5 & $1 / 120$ & $4.993 \pm 0.004$ & undecomposed residue \\
\hline JB-1a & 1.0014 & 30 & 154 & 8 & $1 / 120$ & $5.527 \pm 0.005$ & \\
\hline JB-1a & 1.0015 & 30 & 156 & 10 & $1 / 120$ & $5.555 \pm 0.005$ & \\
\hline JB-1a & 1.0023 & 30 & 154 & 13 & $1 / 120$ & $5.532 \pm 0.005$ & \\
\hline JB-1a & 1.0058 & 30 & 155 & 15 & $1 / 120$ & $5.467 \pm 0.005$ & \\
\hline$\overline{J B}-1 \mathrm{a}$ & 0.5034 & 30 & 160 & 13 & $1 / 60$ & $5.446 \pm 0.011$ & \\
\hline JB-1a & 1.0009 & 30 & 157 & 13 & $1 / 60$ & $5.543 \pm 0.006$ & \\
\hline JB-1a & 1.9998 & 30 & 156 & 13 & $1 / 60$ & $5.595 \pm 0.005$ & \\
\hline JB-1a & 3.0042 & 30 & 157 & 13 & - & - & boiled over \\
\hline JB-1a & 2.5004 & 30 & 158 & 13 & $1 / 60$ & $5.652 \pm 0.005$ & \\
\hline JB-1a & 3.0031 & 50 & 155 & 13 & $1 / 60$ & $5.717 \pm 0.004$ & \\
\hline JA-1 & 1.0016 & 30 & 158 & 18 & $1 / 120$ & $3.749 \pm 0.004$ & \\
\hline JA-1 & 1.0027 & 30 & 152 & 20 & $1 / 120$ & $3.745 \pm 0.004$ & \\
\hline JB-1a & 1.0035 & 30 & 155 & 18 & $1 / 120$ & $5.479 \pm 0.005$ & \\
\hline JB-1a & 1.0063 & 30 & 155 & 20 & $1 / 120$ & $5.485 \pm 0.005$ & \\
\hline JG-3 & 2.0017 & 30 & 154 & 5 & $1 / 120$ & $1.838 \pm 0.002$ & \\
\hline JG-3 & 1.9988 & 30 & 155 & 20 & $1 / 120$ & $1.834 \pm 0.002$ & \\
\hline JB-1a & 3.5022 & 50 & 159 & 13 & - & - & boiled over, undecomposed residue \\
\hline JA-1 & 3.5011 & 50 & 156 & 13 & - & - & boiled over, undecomposed residue \\
\hline $\mathrm{JB}-1 \mathrm{a}$ & 2.0015 & 30 & 157 & 13 & $1 / 60$ & $5.667 \pm 0.005$ & \\
\hline JB-1a & 2.0038 & 30 & 158 & 13 & $1 / 60$ & $5.682 \pm 0.005$ & \\
\hline JB-1a & 2.0017 & 30 & 158 & 13 & $1 / 60$ & $5.663 \pm 0.005$ & \\
\hline JA-1 & 2.0015 & 30 & 159 & 13 & $1 / 60$ & $3.819 \pm 0.004$ & \\
\hline
\end{tabular}

${ }^{a}$ Six samples shown as a group are measured within a single batch. The order within a batch refers to their positions on the sand bath.

${ }^{b}$ The uncertainties in the sample weight, the tolerance of the burette, the uncertainties in the read values of the burette, the uncertainties in the weight of $\mathrm{K}_{2} \mathrm{Cr}_{2} \mathrm{O}_{7}$, and the tolerance of volumetric flask propagated through to the combined standard uncertainties in the FeO determinations.

${ }^{c}$ Remarks only indicate insufficient decomposition. 
tainties in the weight of $\mathrm{K}_{2} \mathrm{Cr}_{2} \mathrm{O}_{7}$, and the tolerance of the volumetric flask were propagated to the combined standard uncertainties in the recovery yield determinations.

$\mathrm{FeO}$ measurements under the condition of $\mathrm{SiO}_{2}$ addition

$\mathrm{FeO}$ values were measured under the condition of adding pure $\mathrm{SiO}_{2}$ powder to the samples. While maintaining the weight of the samples at 0.5 or $1 \mathrm{~g}$, we added $0-2.5 \mathrm{~g}$ of $\mathrm{SiO}_{2}$ powder. The sample powder and $\mathrm{SiO}_{2}$ powder were mixed via swirling with deionized water. This reproduces the decomposition conditions of larger sample volumes without changing the quantities of elements except for that of $\mathrm{SiO}_{2}$.

\section{Design of study and experiments}

The duration of sample decomposition plays a critical role in the method. Both shorter and longer decompositions cause the $\mathrm{FeO}$ values to be underestimated (Maxwell, 1968). While a shorter decomposition duration leads to residual undissolved $\mathrm{FeO}$-bearing minerals, longer decomposition may oxidize $\mathrm{Fe}^{2+}$ to $\mathrm{Fe}^{3+}$. The temperature of the sand bath also must be set properly. The temperature must be high enough to boil the solution, thereby excluding atmospheric oxygen, but not high enough for hot acid to oxidize $\mathrm{Fe}^{2+}$. Given these constraints, we investigated the effect of the: (1) duration of decomposition; (2) temperature of the sand bath; and (3) sample size. First, the duration of decomposition was changed from 3 to 20 minutes, keeping the temperature at $150-160^{\circ} \mathrm{C}$. This was applied for different sample weights ranging from 1 to $3 \mathrm{~g}$, with particularly increased time resolution for the experiments for 1 and $3 \mathrm{~g}$. The geochemical reference material JG-3 (granodiorite) was used as it is considered a representative geochemical reference material. The duration of decomposition for $1 \mathrm{~g}$ of JA-1 (andesite) and $1 \mathrm{~g}$ of JB-1a (basalt) was also tested. Second, the temperature was changed from 150 to $170^{\circ} \mathrm{C}$ in three steps, keeping the weight of the JG-3 at $2 \mathrm{~g}$. To conduct this experiment in a single batch, the depth in the sand bath for the individual sample spots adjusted to obtain the target temperature. Finally, the effect of the weight of sample size on the $\mathrm{FeO}$ values was evaluated. We measured additional aliquots of JG-3 that were double and quadruple the size of the first while also doubling and quadrupling the concentrations of the $\mathrm{K}_{2} \mathrm{Cr}_{2} \mathrm{O}_{7}$ solutions, respectively. This was intended to keep the volume of the titrated $\mathrm{K}_{2} \mathrm{Cr}_{2} \mathrm{O}_{7}$ solution approximately the same to confirm that the effect of the sample weight is not indirectly controlled by the volume of the titrated solution. All results from JG-3 were compiled to investigate the effect of sample weight; these were then further tested on JA-1 and JB-1a. The intention was to examine whether the effect was common among the various sam-

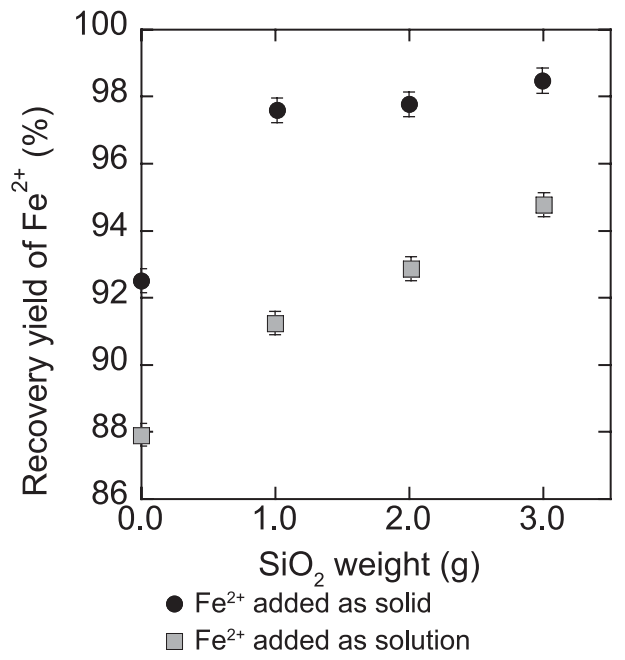

Fig. 6. Relationships between recovery yield of $\mathrm{Fe}^{2+}$ and weight of $\mathrm{SiO}_{2}$ powder. Circles show the recovery yield of $\mathrm{Fe}^{2+}$ when it is added as solid ammonium iron(II) sulphate hexahydrate. Grey squares show recovery yield of $\mathrm{Fe}^{2+}$ when it is added as a solution. Range bars show combined standard uncertainties.

ple types. Fifty-millilitre crucibles were used as using thirty-ml crucibles resulted in boil over. Further, recovery yield of $\mathrm{Fe}^{2+}$ was measured using solid ammonium iron(II) sulphate hexahydrate and $\mathrm{Fe}^{2+}$ solution. Finally, in order to support our findings, FeO values of JG-3 were measured under the condition of adding pure $\mathrm{SiO}_{2}$ powder to the samples.

\section{RESUlTS AND DISCUSSION}

\section{The duration of sample decomposition}

Overall, the $\mathrm{FeO}$ values are relatively constant once the samples are fully decomposed (Figs. 2a-g). While short decomposition durations yield undecomposed residues, which significantly underestimate $\mathrm{FeO}$ values, long decomposition durations do not show a significant loss of $\mathrm{Fe}^{2+}$ due to oxidization. Instead, higher $\mathrm{FeO}$ values are observed with increasing sample weight. The experiments with 1 and $3 \mathrm{~g}$ of JG-3 show that complete decomposition takes 5 minutes regardless of sample size (Figs. 2a and e). While the experiments with 3 minute decomposition durations yield undecomposed residues, 5 minute decomposition durations decompose FeO-bearing minerals completely. After samples are decomposed fully, broad and relatively flat peaks are sustained for 20 minutes of decomposition durations for 1,2 , and $3 \mathrm{~g}$ of JG-3 (Figs. 2a, c, e). The experiments spanning 3-8 minute decomposition durations for $1 \mathrm{~g}$ of JA-1 yield undecomposed residues, indicating that the duration for complete decomposition depends on the sample types (Fig. 2f). For $1 \mathrm{~g}$ of JB-1a, 3-5 minute decomposition 
Table 2. Results of recovery yield of $\mathrm{Fe}^{2+}$

\begin{tabular}{clcccccc}
\hline $\begin{array}{c}\mathrm{SiO}_{2} \\
\text { weight }(\mathrm{g})\end{array}$ & $\mathrm{Fe}^{2+}$ addition & $\begin{array}{c}\text { Ammoniumiron(II) } \\
\text { sulphatehexahydrate }(\mathrm{g})^{\mathrm{a}}\end{array}$ & $\begin{array}{c}\mathrm{Fe}^{2+} \text { solution in } \\
1 \mathrm{~mol} \mathrm{l}^{-1} \mathrm{H}_{2} \mathrm{SO}_{4}(\mathrm{~g})^{\mathrm{b}}\end{array}$ & $\begin{array}{c}\text { Added Fe } \\
(\mathrm{mg})^{\mathrm{c}}\end{array}$ & $\begin{array}{c}\mathrm{Crucible}^{2+} \\
\text { size }(\mathrm{ml})\end{array}$ & $\begin{array}{c}\mathrm{K}_{2} \mathrm{Cr}_{2} \mathrm{O}_{7} \\
\left(\mathrm{~mol} \mathrm{l}^{-1}\right)\end{array}$ & $\begin{array}{c}\mathrm{Recoveryyield}^{2} \\
\mathrm{of} \mathrm{Fe}^{2+}(\%)^{\mathrm{d}}\end{array}$ \\
\hline 0.0000 & added as solid & 0.2520 & - & $35.89 \pm 0.13$ & 30 & $1 / 120$ & $92.50 \pm 0.35$ \\
1.0165 & added as solid & 0.2556 & - & $36.40 \pm 0.14$ & 30 & $1 / 120$ & $97.58 \pm 0.37$ \\
1.9997 & added as solid & 0.2573 & - & $36.64 \pm 0.14$ & 30 & $1 / 120$ & $97.76 \pm 0.37$ \\
2.9956 & added as solid & 0.2561 & - & $36.47 \pm 0.14$ & 30 & $1 / 120$ & $98.46 \pm 0.38$ \\
0.0000 & added as solution & - & 2.2295 & $36.69 \pm 0.14$ & 30 & $1 / 120$ & $87.90 \pm 0.34$ \\
1.0023 & added as solution & - & 2.2241 & $36.60 \pm 0.14$ & 30 & $1 / 120$ & $91.23 \pm 0.35$ \\
2.0150 & added as solution & - & 2.2364 & $36.80 \pm 0.14$ & 30 & $1 / 120$ & $92.86 \pm 0.36$ \\
3.0055 & added as solution & - & 2.2326 & $36.74 \pm 0.14$ & 30 & $1 / 120$ & $94.76 \pm 0.36$ \\
\hline
\end{tabular}

${ }^{a}$ Shown as weight of $\mathrm{Fe}\left(\mathrm{NH}_{4}\right)_{2}\left(\mathrm{SO}_{4}\right)_{2} \cdot 6 \mathrm{H}_{2} \mathrm{O}$. The correction factor of $1.0122 \pm 0.0038$ is determined by five repeatable titrations, employing $1 /$ $120 \mathrm{~mol} \mathrm{l}^{-1} \mathrm{~K}_{2} \mathrm{Cr}_{2} \mathrm{O}_{7}$, and multiplied to the measured weight.

${ }^{b}$ Molar concentration of the solution is $0.2947 \pm 0.0011 \mathrm{mmol} / \mathrm{g} \mathrm{Fe} \mathrm{F}^{2+}$. This is determined by five repeatable titrations with $1 / 120 \mathrm{~mol} \mathrm{l}^{-1}$ $\mathrm{K}_{2} \mathrm{Cr}_{2} \mathrm{O}_{7}$.

${ }^{c}$ Added $\mathrm{Fe}^{2+}$ is calculated from added ammonium iron(II) sulphate hexahydrate or added $\mathrm{Fe}^{2+}$ solution.

${ }^{d}$ The uncertainties of added $\mathrm{Fe}^{2+}$ weight, the tolerance of the burette, the uncertainties in the read values of the burette, the uncertainties in the weight of $\mathrm{K}_{2} \mathrm{Cr}_{2} \mathrm{O}_{7}$, and the tolerance of the volumetric flask propagated through to the combined standard uncertainties in the recovery yield determinations.

(a)

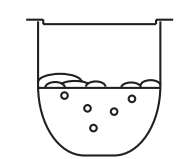

$0.5 \mathrm{~g}$ sample

$3 \mathrm{ml}$ deionized water

$5 \mathrm{ml} \mathrm{H}_{2} \mathrm{SO}_{4}\left(9 \mathrm{~mol} \mathrm{I}^{-1}\right)$

$8 \mathrm{ml} \mathrm{HF}(50 \%)$ (b)

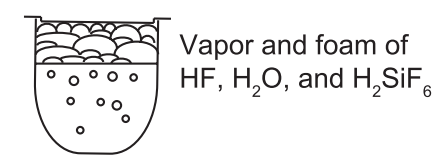

$2.5 \mathrm{~g}$ sample

$3 \mathrm{ml}$ deionized water

$5 \mathrm{ml} \mathrm{H}_{2} \mathrm{SO}_{4}\left(9 \mathrm{~mol} \mathrm{l}^{-1}\right)$

$8 \mathrm{ml} \mathrm{HF}(50 \%)$

Fig. 7. Schematic representations of acid decomposition in platinum crucibles. (a) A sample of $0.5 \mathrm{~g}$ is decomposed in a 30 $\mathrm{ml}$ crucible. $\mathrm{Fe}^{2+}$ is oxidized to $\mathrm{Fe}^{3+}$ by atmospheric oxygen. (b) A sample of $2.5 \mathrm{~g}$ is decomposed in a $30 \mathrm{ml}$ crucible. The vapor and foam on the acid solution prevent loss of $\mathrm{Fe}^{2+}$ due to oxidation.

durations yield undecomposed residues (Fig. 2g). Considering the uncertainty of repeatability, we do not overinterpret the distinct high $\mathrm{FeO}$ values at 7 minutes for JG-3, 10 minutes for JA-1, and 10-13 minutes for JB1a. The relative standard deviation of $0.7 \%$, which is calculated from 9 duplicate measurements at the decomposition time of 12 minutes for the $1 \mathrm{~g}$ of JG-3, exceeds the individual combined standard uncertainties. Consequently, we conducted the rest of the experiments with decomposition durations of 12-13 min, for consistency. This does not influence our conclusions regarding the relationship between sample weight and $\mathrm{FeO}$ values.

\section{The temperature of decomposition}

The $\mathrm{FeO}$ values are relatively constant throughout the variations of the temperature of the sand bath in the range

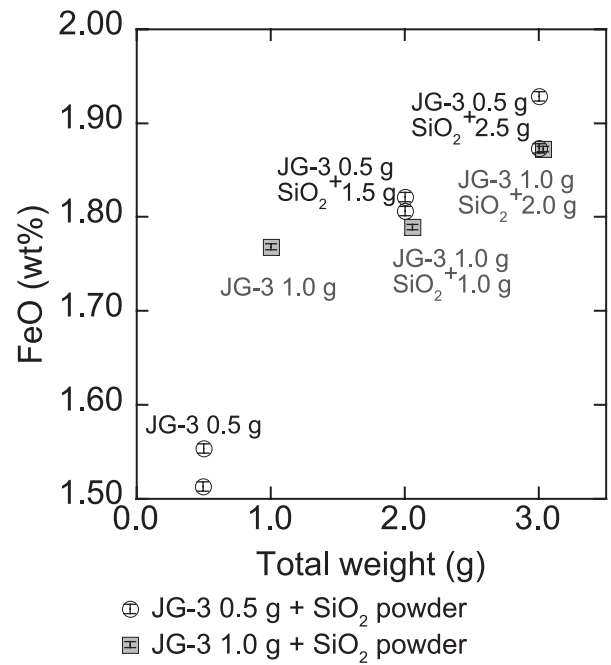

Fig. 8. Effect of sample weight on $\mathrm{FeO}$ values for JG-3. FeO values of JG-3 was measured under the condition of adding pure $\mathrm{SiO}_{2}$ powder to the samples. While maintaining the weight of the $\mathrm{JG}-3$ at 0.5 or $1 \mathrm{~g}$, $\mathrm{SiO}_{2}$ powder was added. Range bars show combined standard uncertainties.

of our experiments. Hence, we maintained the temperature at $150-160^{\circ} \mathrm{C}$ for the rest of the experiments. This supports the view that increasing $\mathrm{FeO}$ values associated with the increasing sample weight is not due to insufficient decomposition duration nor due to insufficient decomposition temperature. The optimum temperature of the sand bath is likely specific to be that of the laboratory, because the actual temperature of the crucibles is balanced between the heat from the sand bath and the cooling wind within the fume hood used in the laboratory. 
Table 3. FeO in JG-3 with addition of pure $\mathrm{SiO}_{2}$ powder

\begin{tabular}{lcccccc}
\hline Sample & $\begin{array}{c}\text { Sample weight } \\
(\mathrm{g})\end{array}$ & $\begin{array}{c}\mathrm{SiO}_{2} \text { weight } \\
(\mathrm{g})\end{array}$ & $\begin{array}{c}\text { Sample }+\mathrm{SiO}_{2} \text { weight } \\
(\mathrm{g})\end{array}$ & $\begin{array}{c}\text { Crucible size } \\
(\mathrm{ml})\end{array}$ & $\begin{array}{c}\mathrm{K}_{2} \mathrm{Cr}_{2} \mathrm{O}_{7} \\
\left(\mathrm{~mol} \mathrm{l}^{-1}\right)\end{array}$ & $\begin{array}{c}\mathrm{FeO} \\
(\mathrm{wt} \%)^{*}\end{array}$ \\
\hline JG-3 & 0.4988 & 0.0000 & 0.4988 & 30 & $1 / 120$ & $1.513 \pm 0.005$ \\
JG-3 & 0.4994 & 1.5054 & 2.0048 & 30 & $1 / 120$ & $1.806 \pm 0.005$ \\
JG-3 & 0.4995 & 2.5039 & 3.0034 & 30 & $1 / 120$ & $1.928 \pm 0.005$ \\
JG-3 & 0.5020 & 0.0000 & 0.5020 & 30 & $1 / 120$ & $1.553 \pm 0.005$ \\
JG-3 & 0.5012 & 1.5033 & 2.0045 & 30 & $1 / 120$ & $1.821 \pm 0.005$ \\
JG-3 & 0.5008 & 2.5012 & 3.0020 & 30 & $1 / 120$ & $1.873 \pm 0.005$ \\
JG-3 & 1.0071 & 0.0000 & 1.0071 & 30 & $1 / 120$ & $1.768 \pm 0.003$ \\
JG-3 & 1.0276 & 1.0330 & 2.0606 & 30 & $1 / 120$ & $1.789 \pm 0.003$ \\
JG-3 & 1.0053 & 2.0257 & 3.0310 & 30 & $1 / 120$ & $1.872 \pm 0.003$ \\
\hline
\end{tabular}

*The uncertainties in the sample weight, the tolerances of the burette, the uncertainties in the read values of the burette, the uncertainties in the weight of $\mathrm{K}_{2} \mathrm{Cr}_{2} \mathrm{O}_{7}$, and the tolerance of the volumetric flask propagated through to the combined standard uncertainties in the FeO determinations.

(a) JG-3

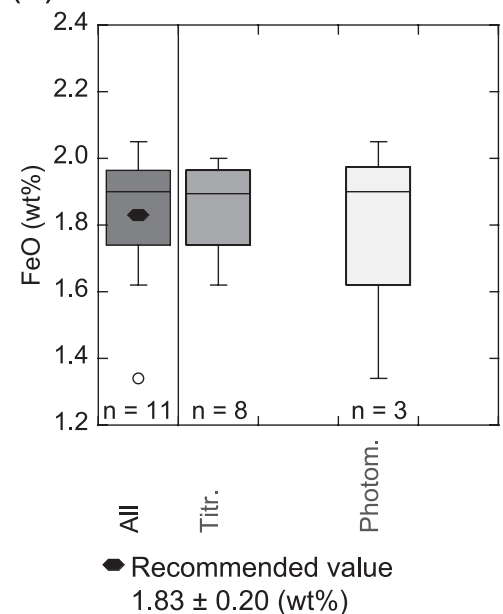

(b) JA-1

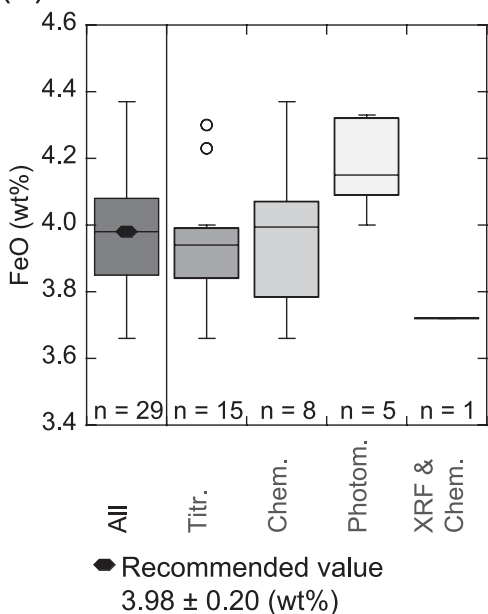

(c) JB-1a

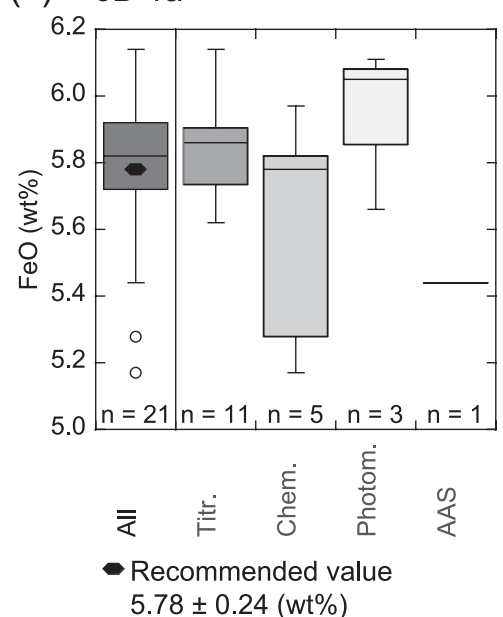

Fig. 9. Recommended values of the geochemical reference materials. All data is from Terashima et al. (1994). Solid hexagons show the recommended values for (a) JG-3, (b) JA-1, and (c) JB-1a. These were determined by averaging all reported values (Terashima et al., 1994). The reported values include those determined by the titrimetric method, "Titr.", conventional chemical method, "Chem.", photometric method, "Photom.", and atomic absorption spectrometry, "AAS". One value for JA-1 is reported as the "X-ray fluorescence (XRF) and conventional chemical method" (Terashima et al., 1994). The quantities of the reported values are shown below each box plot. The boxes define the areas of the first and third quartiles and the solid lines are the medians. The whiskers are data ranges excluding outliers, which are presented as circles. Uncertainties for the recommended values given below the figures are at the ls level.

Relationship between sample weight and $\mathrm{FeO}$ values

Figure 4 shows the $\mathrm{FeO}$ values increased as the sample weight was increased. We measured additional sample aliquots that were double and quadruple in size, while the concentrations of the $\mathrm{K}_{2} \mathrm{Cr}_{2} \mathrm{O}_{7}$ solutions were also doubled and quadrupled, respectively. This enabled the volume of consumed $\mathrm{K}_{2} \mathrm{Cr}_{2} \mathrm{O}_{7}$ solution to be maintained approximately constant as the sample weight was increased. The changes in the volume of the consumed solution could vary the invisible amounts of solution remaining attached to the wall of the burette, thereby affecting the meniscus. Therefore, the results demonstrate that the volume of the consumed solution did not affect the relationship between the sample weight and FeO values.

The measured FeO values of JG-3 are compiled in Fig. 5a. This compilation does not include measurements with insufficient decomposition duration (Table 1). The FeO values increases from $c a$. 1.7 to $1.9 \mathrm{wt} \%$ with increasing sample weight. One-way analysis of variance (ANOVA) supports the view that the $\mathrm{FeO}$ values vary between sample clusters with different sample weights $(p<0.01)$. Measurements with sample sizes of $3.5 \mathrm{~g}$ using $30 \mathrm{ml}$ crucibles resulted in boil over (Table 1). Although we 
obtained some successful results with $50 \mathrm{ml}$ crucibles for $4 \mathrm{~g}$ samples (Fig. 5a), measurements with sample sizes of 5 and $6 \mathrm{~g}$ all failed (Table 1). Large samples caused intense reactions in the crucibles, thereby producing large amounts of foam, which raised the covers and overflowed the crucibles. Large samples caused undecomposed residues to become caked on the bottom of the crucibles and the underside of the covers. As a result, $4 \mathrm{~g}$ is the maximum sample weight of JG-3 that can be treated with this method. The increase in $\mathrm{FeO}$ values with increasing sample weight was also observed for JA-1 and JB-1a (Figs. 5b and c), indicating this trend is general among majority of reference materials. Samples heavier than $3 \mathrm{~g}$ result in boil over and remaining undecomposed residues for JA-1 and JB-1a (Table 1), implying $3 \mathrm{~g}$ is the maximum sample weight for these two reference materials.

\section{Effect of vapor and foam}

The results of the recovery yield tests show increasing recovery of $\mathrm{Fe}^{2+}$ with increasing weight of $\mathrm{SiO}_{2}$ powder (Fig. 6, Table 2). The recovery yield of $\mathrm{Fe}^{2+}$ from solid ammonium iron(II) sulphate hexahydrate increased significantly under the condition of $1 \mathrm{~g} \mathrm{SiO}_{2}$ powder, compared to that of the experiment that did not utilize $\mathrm{SiO}_{2}$ powder. The recovery yield then increased gradually to $98.46 \pm 0.38 \%$ when decomposed with $3 \mathrm{~g}$ of $\mathrm{SiO}_{2}$ powder. This demonstrates that loss of $\mathrm{Fe}^{2+}$ is reduced to $1.5 \%$ in the ideal case. The increase in recovery yields with increasing $\mathrm{SiO}_{2}$ weight was also observed when $\mathrm{Fe}^{2+}$ was added in the form of solution. However, the values were low compared to those of the experiments where $\mathrm{Fe}^{2+}$ was added in the form of solid salt. Given that $\mathrm{Fe}^{2+}$ is released into solution gradually in hot $\mathrm{HF}$ in the case of actual silicate minerals, we consider that $\mathrm{Fe}^{2+}$ addition in the solid phase resembles the treatments of actual samples more. The experiments involving $\mathrm{Fe}^{2+}$ addition in the form of solution represent the worst-case scenarios wherein all the $\mathrm{Fe}^{2+}$ in samples is released into the solution before addition of the decomposing acid, which is not likely to be the case for actual samples. Nonetheless, the results of $\mathrm{Fe}^{2+}$ addition in the form of solution suggest that insufficient treatments in wet chemical analysis may cause non-negligible loss of $\mathrm{Fe}^{2+}$, which is $5 \%$ for the yield test when decomposed with $3 \mathrm{~g}$ of $\mathrm{SiO}_{2}$ powder.

From our observations, the increase in $\mathrm{FeO}$ values with increasing weight of the reference materials, which is supported by the recovery yield tests, is most likely due to the fact that the vapor and the foam on the acid solution prevent oxidation (Fig. 7). Larger samples generate more continuous vapor flow of $\mathrm{H}_{2} \mathrm{O}, \mathrm{HF}$, and $\mathrm{H}_{2} \mathrm{SiF}_{6}$, shutting out the atmospheric oxygen. Larger samples also produce larger amounts of foam that prevent the solution from contacting with the atmospheric oxygen. The amount of oxidized $\mathrm{Fe}^{2+}$ is minimized with larger samples that re- duce the open spaces in the crucible as much as possible. Maximum FeO is therefore obtained with sample weights that are slightly less than the weight that causes boil over (Fig. 5, Table 1). Similarly, the relationship between the weight of $\mathrm{SiO}_{2}$ powder and the recovery yield of $\mathrm{Fe}^{2+}$ implies that oxidation of $\mathrm{Fe}^{2+}$ in solution is significant until the vapor and the foam on the acid solution prevent contact with atmospheric oxygen.

Low concentrations of carbon in igneous rock series of reference materials suggest that the increase in $\mathrm{FeO}$ values with sample weight is not due to the consumption of $\mathrm{K}_{2} \mathrm{Cr}_{2} \mathrm{O}_{7}$ by the organic matter contained in the samples. For example, carbon mass fractions are only 120 , 271 , and $312 \mu \mathrm{g} \mathrm{g}^{-1}$ for JG-3, JA-1, and JB-1a, respectively (Imai et al., 1995), indicating that the consumption of $\mathrm{K}_{2} \mathrm{Cr}_{2} \mathrm{O}_{7}$ is negligible. The results are not affected by the presence of sulphide because sulphur mass fractions are only 54.7, 21.6, and $10.2 \mu \mathrm{g} \mathrm{g}^{-1}$ for JG-3, JA-1, and JB-1a, respectively (Imai et al., 1995). This is supported by the recovery yield tests. Furthermore, this is also supported by the results of adding pure $\mathrm{SiO}_{2}$ powder to JG-3 (Fig. 8, Table 3). The experiments permitted us to examine the effect of the vapor and the foam without changing the amount of organic matter in the samples. Addition of pure $\mathrm{SiO}_{2}$ powder effectively increased $\mathrm{FeO}$ values for 0.5 and $1 \mathrm{~g}$ of JG-3 (Fig. 8). Increasing the amount of pure $\mathrm{SiO}_{2}$ powder enhanced the reactions in the crucibles, thereby producing large amounts of vapor and foam preventing oxidation. The trend of increasing $\mathrm{FeO}$ values with increasing total weight of the samples (Fig. 8) is the same, as is observed from the experiments that simply employ increasing sample weights (Fig. 5a). Additionally, we note that $\mathrm{K}_{2} \mathrm{Cr}_{2} \mathrm{O}_{7}$ consumes much less organic matter compared to permanganate that is sometimes used for titrimetric solutions (Sarver, 1927).

\section{Comparison with the recommended values}

We compared our results with the recommended values of the geochemical reference materials (Fig. 9, Supplementary Table S1). The reference materials we measured in this study are those that had been issued early-on in the program. The recommended values at that time were determined by averaging reported values from researchers following wide distribution of the materials (Terashima et al., 1994). The reported values were mainly obtained by titrimetric method, but include values determined by other methods such as conventional chemical method, the photometric method, and atomic absorption spectrometry (AAS). In Terashima et al. (1994), wet chemical values that was not clearly reported as titrimetric values were classified as the conventional chemical method. We note that the certified values of $\mathrm{FeO}$ in recently issued reference materials from the GSJ are collaboratively determined using the titrimetric method only 
(Okai, 2016).

The variation of the $\mathrm{FeO}$ values associated with sample weight is within the variation of the recommended values (Fig. 9). Thus, the dependency of the $\mathrm{FeO}$ values on sample weight is a variation within a very narrow range. The average and the standard deviation of 3 values from our study with $4 \mathrm{~g}$ samples (Fig. 5a) provides $1.89 \pm 0.01 \mathrm{wt} \%$ for JG-3. This value is consistent with the recommend value of $1.83 \pm 0.20 \mathrm{wt} \%$ (Terashima $e t$ al., 1994) (Fig. 9a), and close to the original value of 1.91 wt\% reported by the GSJ (Terashima and Ando, 1987). The titrimetric and photometric methods are indistinguishable with respect to JG-3. The highest $\mathrm{FeO}$ value of 3.91 wt $\%$ for JA-1 from our measurements (Fig. 5b) is consistent with the recommended value of $3.98 \pm 0.20 \mathrm{wt} \%$ (Terashima et al., 1994) (Fig. 9b). Revisiting the original values reported using the Kruskal-Wallis test, we observe that the photometric method provides higher values compared to the titrimetric method $(p<0.05)$. If we compile the reported values by titrimetric method only, the $\mathrm{FeO}$ value is $3.94 \pm 0.17 \mathrm{wt} \%$. The highest $\mathrm{FeO}$ value of 5.72 wt $\%$ for JB-1a from our measurements (Fig. 5c) is consistent with the recommended value of $5.78 \pm 0.24 \mathrm{wt} \%$ (Terashima et al., 1994) (Fig. 9c), although it is slightly lower than the original value of $5.92 \mathrm{wt} \%$ reported by the GSJ (Terashima and Ando, 1987). No statistical difference was observed between the methods, although the conventional chemical method provides visually lower values for JB-1a.

\section{Modification of the method and applications}

We suggest that using greater amounts of sample provides an easy means to minimize oxidation during sample decomposition, thereby allowing for more accurate determination of $\mathrm{FeO}$ in geochemical reference materials and unknown geological samples. We also stress that a slight loss of $\mathrm{Fe}^{2+}$ is unavoidable, as shown by the recovery yield tests. The maximum sample weight that can be treated within typical $30 \mathrm{ml}$ crucibles is 2.5 or $3 \mathrm{~g}$, depending on the sample type. In contrast, the typical sample weight in the literature is $c a$. 0.5-1.0 g (Maxwell, 1968; Jeffery, 1970; Bennett and Reed, 1971; Saikkonen and Rautiainen, 1993). To the best of our knowledge, trials to test larger samples have never been reported. Similarly, adding pure $\mathrm{SiO}_{2}$ powder to samples helps to minimize oxidation. While just using greater quantities of sample is simpler, adding pure $\mathrm{SiO}_{2}$ powder proves effective when the $\mathrm{FeO}$ value is large enough to prevent usage of large samples size in terms of the concentration of $\mathrm{K}_{2} \mathrm{Cr}_{2} \mathrm{O}_{7}$ solution and the maximum volume of a burette.

Some studies use the "Wilson method" to measure $\mathrm{FeO}$ (Wilson, 1960; Whipple, 1974; Amonette and Scott, 1991; Andrade et al., 2002). In that method, $\mathrm{Fe}^{2+}$ is deliberately oxidized to $\mathrm{Fe}^{3+}$ by an oxidizing agent such as am- monium metavanadate, the excess of which is determined using a titrimetric method. Discrepancies in the $\mathrm{FeO}$ values obtained from the "Pratt method" and "Wilson method" are often reported, and are attributed either to unexpected oxidation of $\mathrm{Fe}^{2+}$ in the "Pratt method" or to complex interference of the sample matrix with the oxidizing agent in the "Wilson method" (Saikkonen and Rautiainen, 1993; Lalonde et al., 1998; Yokoyama and Nakamura, 2002; Amonette and Matyas, 2016; Xue et al., 2017). Although the "Wilson method" has been developed to overcome the disadvantage of unexpected oxidation of $\mathrm{Fe}^{2+}$ in the "Pratt method", the behaviour of the oxidizing agent in the sample matrix is partly still unclear. Whipple (1974) reported that oxidation of $\mathrm{Fe}^{2+}$ or $\mathrm{V}^{4+}$ occurs in the "Wilson method". The degree to which the oxidizing agent is being consumed by sulphur and other elements such as $\mathrm{Ti}^{3+}$ in the samples remains uncertain (Schafer, 1966a; Saikkonen and Rautiainen, 1993). Our simple modification of the "Pratt method" using a greater amount of the sample will therefore provide opportunities to evaluate the difference between these two methods.

\section{CONCLUSIONS}

We have presented the optimization of a titrimetric method to determine $\mathrm{FeO}$ in geological materials. We tested the effect of the duration of decomposition, the temperature of a sand bath, and the sample weight. A duration of $12-13 \mathrm{~min}$ at $150-160^{\circ} \mathrm{C}$ is sufficient for the acid decomposition using a mixture of $5 \mathrm{ml}$ of $9 \mathrm{~mol} \mathrm{l}^{-1} \mathrm{H}_{2} \mathrm{SO}_{4}$ and $8 \mathrm{ml}$ of $50 \% \mathrm{HF}$. The $\mathrm{FeO}$ values increase with increasing sample weight until the sample weight reaches the weight that causes boil over. This is most likely owing to the fact that the vapor and the foam on the acid solution prevent loss of $\mathrm{Fe}^{2+}$ due to oxidation. We suggest that using a greater amount of sample provides an easy means to minimize oxidation during sample decomposition, thereby allowing a better determination of $\mathrm{FeO}$ in geochemical reference materials and unknown geological samples. The maximum sample weight that can be treated within typical $30 \mathrm{ml}$ crucibles is 2.5 or $3 \mathrm{~g}$, depending on the sample type. In contrast, $50 \mathrm{ml}$ crucibles are sufficient to treat 3 to $4 \mathrm{~g}$ samples. We also note, however, that slight loss of $\mathrm{Fe}^{2+}$ is unavoidable; therefore, and $\mathrm{FeO}$ values with low sample weight obtained from the modified version of the Pratt method need to be carefully considered. The recovery yield tests with $3 \mathrm{~g}$ of $\mathrm{SiO}_{2}$ powder demonstrate that loss of $\mathrm{Fe}^{2+}$ is $1.5 \%$ in the ideal case and 5\% in the worst case. Previously published recommended values of $\mathrm{FeO}$ for geochemical reference materials are averages, including those determined using several methods; therefore, they need to be considered carefully. 
Acknowledgments-We would like to thank all the researchers involved in issuing geochemical reference materials at the GSJ, and we would also like to thank H. St. C. O'Neill and the other anonymous reviewer for their helpful comments. This work was supported by the GSJ grant for reference materials, and partly supported by JSPS KAKENHI (grant number 18K13624).

\section{REFERENCES}

Amonette, J. E. and Matyas, J. (2016) Determination of ferrous and total iron in refractory spinels. Anal. Chim. Acta 910, 25-35.

Amonette, J. E. and Scott, A. D. (1991) Determination of ferrous Iron in non-refractory silicate minerals 1 . An improved semi-micro oxidimetric method. Chem. Geol. 92, 329-338.

Andrade, S., Hypolito, R., Ulbrich, H. H. G. J. and Silva, M. L. (2002) Iron(II) oxide determination in rocks and minerals. Chem. Geol. 182, 85-89.

Barnebey, O. L. (1915) Permanganate determination of iron in the presence of fluorides - the analysis of silicates and carbonates for their ferrous iron content. Am. Chem. Soc. 37, 1481-1496.

Bennett, H. and Reed, R. A. (1971) Chemical Methods of Silicate Analysis-A Handbook. Academic Press, 272 pp.

Berry, A. J., Yaxley, G. M., Woodland, A. B. and Foran, G. J. (2010) A XANES calibration for determining the oxidation state of iron in mantle garnet. Chem. Geol. 278, 31-37.

Berry, A. J., Stewart, G. A., O’Neill, H. St. C., Mallmann, G. and Mosselmans, J. F. W. (2018) A re-assessment of the oxidation state of iron in MORB glasses. Earth Planet. Sci. Lett. 483, 114-123.

Bézos, A. and Humler, E. (2005) The $\mathrm{Fe}^{3+} / \Sigma \mathrm{Fe}$ ratios of MORB glasses and their implications for mantle melting. Geochim. Cosmochim. Acta 69, 711-725.

Christie, D. M., Carmichael, I. S. E. and Langmuir, C. H. (1986) Oxidation states of mid-ocean ridge basalt glasses. Earth Planet. Sci. Lett. 79, 397-411.

Cooke, J. P. (1867) A method of determining the amount of protoxide of iron in silicates not soluble in the ordinary mineral acids. Am. J. Sci. 44, 347-350.

Cottrell, E. and Kelley, K. A. (2011) The oxidation state of Fe in MORB glasses and the oxygen fugacity of the upper mantle. Earth Planet. Sci. Lett. 305, 270-282.

Farges, F. (2001) Crystal chemistry of iron in natural grandidierites: an X-ray absorption fine-structure spectroscopy study. Phys. Chem. Min. 28, 619-629.

Hillebrand, W. F. (1907) The analysis of silicate and carbonate rocks, USGS Numbered Series. Government Printing Office, $200 \mathrm{pp}$.

Hughes, E. C., Buse, B., Kearns, S. L., Blundy, J. D., Kilgour, G., Mader, H. M., Brooker, R. A., Balzer, R., Botcharnikov, R. E., Di Genova, D., Almeev, R. R. and Riker, J. M. (2018) High spatial resolution analysis of the iron oxidation state in silicate glasses using the electron probe. Am. Mineral. 103, 1473-1486.

Husler, J., Ferriss, E. D., Helean, K. B., Bryan, C. R. and Brady, P. V. (2011) Optimised ferrozine micro-method for the determination of ferrous and ferric iron in rocks and miner- als. Geostand. Geoanal. Res. 35, 39-44.

Imai, N., Terashima, S., Itoh, S. and Ando, A. (1995) 1994 compilation values for GSJ reference samples, "Igneous rock series". Geochem. J. 29, 91-95.

Jeffery, P. G. (1970) Chemical Methods of Rock Analysis. Pergamon Press, 509 pp.

Kanai, Y. (1990) Simultaneous determination of Iron(II) and Iron(III) oxides in geological materials by ion chromatography. Analyst 115, 809-812.

Lalonde, A. E., Rancourt, D. G. and Ping, J. Y. (1998) Accuracy of ferric/ferrous determinations in micas: A comparison of Mössbauer spectroscopy and the Pratt and Wilson wet-chemical methods. Hyperfine Interactions 117, 175204.

le Roex, A. P. and Watkins, R. T. (1995) A rapid ion-chromatographic method for the determination of the $\mathrm{Fe}^{3+} / \mathrm{Fe}^{2+}$ ratio in silicate rocks and minerals. Geochem. J. 29, 85-89.

Li, X., Zhang, C., Almeev, R. R., Zhang, X. C., Zhao, X. F., Wang, L. X., Koepke, J. and Holtz, F. (2019) Electron probe microanalysis of $\mathrm{Fe}^{2+} / \Sigma \mathrm{Fe}$ ratios in calcic and sodic-calcic amphibole and biotite using the flank method. Chem. Geol. 509, 152-162.

Maxwell, J. A. (1968) Rock and Mineral Analysis. Interscience Publ., 584 pp.

Middlemost, E. A. K. (1989) Iron oxidation ratios, norms, and the classification of volcanic rocks. Chem. Geol. 77, 1926.

Ohta, A., Tsuno, H., Kagi, H., Kanai, Y., Nomura, M., Zhang, R., Terashima, S. and Imai, N. (2006) Chemical compositions and XANES speciations of $\mathrm{Fe}, \mathrm{Mn}$ and $\mathrm{Zn}$ from aerosols collected in China and Japan during dust events. Geochem. J. 40, 363-376.

Okai, T. (2016) Development and utilization of geochemical reference materials-Reliability improvement in the analysis of geological materials-. Synthesiology English edition 9, 60-73.

O’Neill, H. St. C., Berry, A. J., McCammon, C. C., Jayasuriya, K. D., Campbell, S. J. and Foran, G. (2006) An experimental determination of the effect of pressure on the $\mathrm{Fe}^{3+} / \sum \mathrm{Fe}$ ratio of an anhydrous silicate melt to $3.0 \mathrm{GPa}$. Am. Mineral. 91, 404-412.

O'Neill, H. St. C., Berry, A. J. and Mallmann, G. (2018) The oxidation state of iron in Mid-Ocean Ridge Basaltic (MORB) glasses: Implications for their petrogenesis and oxygen fugacities. Earth Planet. Sci. Lett. 504, 152-162.

Pratt, J. H. (1894) On the determination of ferrous iron in silicates. Am. J. Sci. 48, 149-151.

Saikkonen, R. J. and Rautiainen, I. A. (1993) Determination of ferrous iron in rock and mineral samples by three volumetric methods. Bull. Geol. Soc. Finland 65, 59-63.

Sarver, L. A. (1927) The determination of ferrous iron in silicates. J. Am. Chem. Soc. 49, 1472-1477.

Schafer, H. N. S. (1966a) The determination of iron(II) oxide in silicate and refractory materials part I. A review. Analyst 91, 755-762.

Schafer, H. N. S. (1966b) The determination of iron(II) oxide in silicate and refractory materials part II. A semi-micro titrimetric method for determining iron(II) oxide in silicate materials. Analyst 91, 763-770. 
Stolper, D. A. and Keller, C. B. (2018) A record of deep-ocean dissolved $\mathrm{O}_{2}$ from the oxidation state of iron in submarine basalts. Nature 553, 323-327.

Tarafder, P. K. and Thakur, R. (2013) An optimised 1,10phenanthroline method for the determination of ferrous and ferric oxides in silicate rocks, soils, and minerals. Geostand. Geoanal. Res. 37, 155-168.

Terashima, S. and Ando, A. (1987) Elemental concentrations in nine new Japanese rock reference samples. Geostand. Newsl. 11, 75-77.

Terashima, S., Imai, N., Itoh, S., Ando, A. and Mita, N. (1994) 1993 compilation of analytical data for major elements in seventeen GSJ geochemical reference samples, "Igneous rock series". Bull. Geol. Surv. Japan 45, 305-381.

Verma, S. P., Torres-Alvarado, I. S. and Sotelo-Rodriguez, Z. T. (2002) SINCLAS: standard igneous norm and volcanic rock classification system. Computers \& Geosciences $\mathbf{2 8}$, 711-715.

Whipple, E. R. (1974) Study of Wilsons determination of ferrous iron in silicates. Chem. Geol. 14, 223-238.

Wilson, A. D. (1960) The micro-determination of ferrous iron in silicate minerals by a volumetric and a colorimetric method. Analyst 85, 823-827.

Xue, D. S., Wang, H. Y., Liu, Y. H., Xie, L. W. and Shen, P. (2017) An improved procedure for the determination of ferrous iron mass fraction in silicate rocks using a Schlenk line-based digestion apparatus to exclude oxygen. Geostand. Geoanal. Res. 41, 411-425.

Yokoyama, T. and Nakamura, E. (2002) Precise determination of ferrous iron in silicate rocks. Geochim. Cosmochim. Acta 66, 1085-1093.

Zhang, H. L., Cottrell, E., Solheid, P. A., Kelley, K. A. and Hirschmann, M. M. (2018) Determination of $\mathrm{Fe}^{3+} / \Sigma \mathrm{Fe}$ of XANES basaltic glass standards by Mössbauer spectroscopy and its application to the oxidation state of iron in MORB. Chem. Geol. 479, 166-175.

\section{SUPPLEMENTARY MATERIALS}

URL (http://www.terrapub.co.jp/journals/GJ/archives/ data/54/MS605.pdf)

Table S1 